\title{
A Codominant Randomly Amplified Polymorphic DNA (RAPD) Marker Useful for Indirect Selection of Bean Golden Mosaic Virus Resistance in Common Bean
}

\author{
Carlos A. Urrea ${ }^{1}$ and Phillip N. Miklas ${ }^{2,5}$ \\ Tropical Agriculture Research Station, Agricultural Research Service, U.S. Department of Agriculture, \\ Mayagüez, PR 00681
}

James S. Beaver
Department of Agronomy and Soil Science, University of Puerto Rico, Mayagüez, PR 00681

Ronald H. Riley ${ }^{4}$

Rogers Seed Company, Research Center, 6338 Highway 20-26, Nampa, ID 83867

Additional index words. bean golden mosaic virus, DNA markers, dry bean, Phaseolus vulgaris, snap bean

\begin{abstract}
Bean golden mosaic virus (BGMV) is a devastating disease of common bean (Phaseolus vulgaris L.) in tropical America. The disease is effectively controlled by combinations of genetic resistances. The most widely deployed source of resistance to BGMV is a recessive gene $(\mathrm{bgm}-1)$ derived from the dry bean landrace cultivar Garrapato (Mexico) that conditions a nonmosaic partial resistance response to the pathogen. To expedite introgression of partial resistance into snap bean for southern Florida and other susceptible dry bean market classes for the Caribbean and Central American regions, a RAPD marker tightly linked to $\mathrm{bgm}-1$ has been identified. Two contrasting DNA bulks, one consisting of five BGMV-resistant and the other five susceptible $F_{6}$ recombinant inbred lines, were used to screen for polymorphic fragments amplified by 300 decamer primers in the polymerase chain reaction. RAPDs generated between the bulks were analyzed across $F_{2}$ populations segregating for the marker and the gene. One codominant RAPD marker $\left(\mathbf{R 2}_{570 / 530}\right)$ tightly linked to the recessive resistance gene $\mathrm{bgm}-1$ was found. The 530-base pair (bp) fragment was linked in repulsion with $b g m$ 1 and the other 570-bp fragment was linked in coupling. No recombinants between $\mathrm{R}_{570 / 530}$ and $\mathrm{bgm-1}$ were observed among $91 \mathrm{~F}_{2}$ progeny from one dry bean population, and there were two recombinants $(4.2 \mathrm{cM})$ observed among $48 \mathrm{~F}_{2}$ progeny combined across four snap bean populations. Assays of $\mathbf{R 2}_{570 / 530}$ across susceptible germplasm and lines likely to have the 'Garrapato'-derived partial resistance to BGMV have revealed that the codominant marker is gene-pool nonspecific and maintains its original linkage orientation with the recessive bgm-1 gene through numerous meioses. The codominant marker is useful for rapidly introgressing partial resistance to BGMV into susceptible germplasm.
\end{abstract}

Bean golden mosaic virus (BGMV) is the most serious viral disease of common bean (Phaseolus vulgaris L.) in Latin America (Gálvez and Morales, 1989). Bean golden mosaic is caused by a geminivirus (Maxwell et al., 1994) vectored by the whiteflies Bemisia tabaci (Bellows and Perring) and B. argentifolii (Genn.) (Gálvez and Morales, 1989). BGMV has been reported in southern Florida where it has devastated snap bean production (Blair et al., 1995).

Genetic resistance to BGMV has proven to be an effective form of disease control (Beebe, 1994; Morales and Singh, 1991). The first BGMV resistant cultivars ('Jutiapan', 'Ostua', and 'Quetzal', etc.) have been developed by International Center for Tropical Agriculture (CIAT) and Agricultural Institute of Science and

Received for publication 3 Jan. 1996. Accepted for publication 4 June 1996. This report summarizes, in part, a Cooperative Research and Development Agreement 58-3K95-4-259 between the U.S. Dept. of Agriculture, Agricultural Research Service, and Rogers Seed Co. We acknowledge Matthew Blair for disease characterization and development of the RIL population; Albeiro Molina, José Vélez, and Maximo Halpay for assisting with greenhouse disease screening; and Nada Abbas for assisting with randomly amplified polymorphic DNA analyses. The cost of publishing this paper was defrayed in part by the payment of page charges. Under postal regulations, this paper therefore must be hereby marked advertisement solely to indicate this fact.

${ }^{1}$ Graduate assistant.

${ }^{2}$ Research geneticist.

${ }^{3}$ Associate professor.

${ }^{4}$ Plant breeder.

${ }^{5}$ To whom reprint requests should be addressed. Current address: USDA-ARSIAREC, 24106 N. Bunn Rd., Prosser, WA 99350-9687.
Technology (ICTA), Guatemala, breeders for Central America. These cultivars derived reduced mosaic and superior yielding resistance from 'Porrillo Sintético' (G4495) and diffuse mottling resistance from Turrialba 1 (Beebe and Pastor-Corrales, 1991). Newly released cultivars, such as 'Dorado' (formerly DOR 364), 'Don Silvio' (formerly DOR 482), and 'Turbo III', have culminated $\approx 16$ years of breeding for BGMV resistance $(\mathrm{S}$. Beebe, personal communication). These cultivars have greater resistance to BGMV obtained from various combinations of partial resistances derived from 'Porrillo Sintético' and 'Turrialba 1', partial "nonmosaic" resistance of 'Garrapato' (G 2402), and tolerance of 'Honduras 46' (G 4791). Generally, in our breeding program and elsewhere (CIAT, 1995), new lines and cultivars with high levels of BGMV resistance carry the 'Garrapato' source of partial resistance in their pedigree.

Lack of expression of mosaic symptoms from 'Garrapato', following inheritance studies involving the breeding line A429, was conditioned by a single recessive gene (Blair and Beaver, 1993). In our paper, we have assigned a tentative symbol, bgm-1, to represent this recessive resistance gene. To date, bgm-1 is widely used as a source of partial BGMV resistance. The resistance is considered partial because low yield and pod deformation are observed under moderate to high levels of disease incidence. Introgression of $b g m-1$ is an important first step in breeding new BGMV-resistant cultivars. Combining bgm- 1 with other resistance genes that condition high yield is also important (Beebe, 1994).

For introgression purposes, the recessive nature of bgm-1 
requires a generation of selfing after every second to third backcross generation to obtain homozygous resistant $\mathrm{BC}_{\mathrm{n}} \mathrm{F}_{2}$ parents for the next backcross cycle. Other obstacles associated with breeding for BGMV resistance include lack of uniform and consistent yearto-year disease pressure in the field. Greenhouse programs that use viruliferous whiteflies (Beaver et al., 1994) or a mechanical form of inoculation (Morales and Niessen, 1988) provide uniform inoculum, but risk introducing the virus into new regions, are timeconsuming and do not provide reliable yield data.

Marker-assisted selection provides an ideal strategy for transferring and combining monogenic resistance traits in common bean (Kelly, 1995). Indirect selection of a recessive resistance gene based on a closely linked randomly amplified polymorphic DNA (RAPD) marker (Welsh and McClelland, 1990; Williams et al., 1990) can reduce the number of generations required in a backcross breeding program and limit the need for greenhouse and field testing. Our objective was to obtain a gene-pool-nonspecific (Young and Kelly, 1996) RAPD marker tightly linked to the recessive bgm-1 gene from 'Garrapato' that conditions partial nonmosaic resistance to BGMV. Identifying a dominant RAPD in repulsion-phase linkage with $b g m-1$ is desired for rapid backcrossing of partial resistance to BGMV into susceptible types (Johnson et al., 1995).

\section{Materials and Methods}

Plant material. Random $\mathrm{F}_{5: 6}$ recombinant inbred lines (RILs) segregating for the recessive bgm-1 gene from 'Garrapato' that conditions nonmosaic partial resistance to BGMV were derived from a T446/A429 hybridization using single-seed descent. The RILs were used with DNA bulked segregant analysis (Michelmore et al., 1991) to initially screen 300 hundred arbitrary decamer primers in the polymerase chain reaction (PCR) for identifying RAPDs putatively linked to the $b g m-1$ locus. T446 is an advanced pinto bean breeding line with high yield potential in the tropics. A429 is an advanced pinto breeding line from CIAT with upright architecture and combined BGMV resistances from 'Porrillo Sintético' and 'Garrapato'.

$R A P D$ protocols. DNA was extracted using a modified "mini-

Table 1. Chi-square tests for phenotypic segregation at the $b g m-1$ locus that confers partial resistance to bean golden mosaic virus and segregation at the $\mathrm{R} 2_{570 / 530}$ codominant RAPD marker locus and linkage estimates between the two loci.

\begin{tabular}{|c|c|c|c|c|c|}
\hline $\begin{array}{l}\mathrm{F}_{2} \\
\text { population }\end{array}$ & $\begin{array}{l}\text { No. of } \\
\text { progeny }\end{array}$ & Observed & Expected & $\chi^{2}$ & $\mathrm{P}$ \\
\hline \multicolumn{6}{|l|}{$\begin{array}{l}\text { Resistant gene } \\
\quad(1 \text { resistant : } 3 \text { susceptible })\end{array}$} \\
\hline Dry bean & 91 & $22: 69$ & 23:68 & 0.03 & $>0.80$ \\
\hline Snap bean & 48 & $6: 42$ & $12: 36$ & 4.00 & $>0.01$ \\
\hline \multicolumn{6}{|l|}{ Codominant RAPD } \\
\hline \multicolumn{6}{|l|}{$\mathrm{R} 2_{570 / 530}(1-/+: 2+/+: 1+/-)^{\mathrm{z}}$} \\
\hline Dry bean & 91 & $22: 47: 22$ & $23: 45: 23$ & 0.10 & $>0.50$ \\
\hline Snap bean & 48 & $8: 34: 6$ & $12: 24: 12$ & 11.00 & $>0.01$ \\
\hline Marker-gene & \multicolumn{5}{|c|}{ Linkage distance } \\
\hline Dry bean (zero recombinants) & \multicolumn{5}{|c|}{$-\mathrm{cM}$} \\
\hline Snap bean (two recombinants) & \multicolumn{5}{|c|}{$4.2 \mathrm{cM}$} \\
\hline Across populations & \multicolumn{5}{|c|}{$1.4 \mathrm{cM}$} \\
\hline
\end{tabular}

${ }_{\text {ZPhenotypes for the codominant R2 }}{ }_{570 / 530}$ RAPD marker: -/+, 570-base pair (bp) fragment allele absent/530bp fragment allele present, and the RAPD phenotype indicating homozygous resistance (bgm-1bgm- 1 )at the linked recessive gene locus; $+/+$, both fragment alleles present indicating heterozygous susceptible (Bgm1 bgm-1); and $+/-$, 570-bp fragment allele present/530-bp fragment allele absent indicating homozygous susceptible (Bgm-1Bgm-1). prep" procedure (Afanador et al., 1993), quantified by fluorometry (Hoefer TKO 100, Hoefer Scientific, San Francisco), and standardized to $10 \mathrm{ng} \cdot \mu \mathrm{L}^{-1}$. Two contrasting DNA bulks were formed, one with five $\mathrm{F}_{6}$ RILs with uniform nonmosaic resistance and the other with five $\mathrm{F}_{6}$ RILs with uniform susceptibility. Uniformity of disease reaction of selected RILs initially was based on natural infection in the field and then later confirmed by greenhouse inoculations using whiteflies viruliferous for the Puerto Rican strain of BGMV (Beaver et al., 1994). DNA bulks were screened with 300 decamer primers (Operon Technologies, Alameda, Calif.).

The PCR consisted of $25-\mu \mathrm{L}$ reactions containing two units of Stoffel fragment DNA polymerase (Perkin Elmer Cetus, Norwalk, Conn.), $1 \times$ Stoffel buffer, $5 \mathrm{~mm} \mathrm{MgCl}, 200 \mathrm{~m}$ of each dNTP, 0.2 primer, and $25 \mathrm{ng}$ template DNA. A DNA thermal cycler (mode 480; Perkin Elmer) was used. The thermo-cycling profile consisted of three initial cycles of denaturing at $94^{\circ} \mathrm{C}$ for $1 \mathrm{~min}$, annealing at $35^{\circ} \mathrm{C}$ for $1 \mathrm{~min}$, and extension at $72{ }^{\circ} \mathrm{C}$ for $2 \mathrm{~min}$, owed by 31 cycles of $94^{\circ} \mathrm{C}$ for $10 \mathrm{~s}, 40^{\circ} \mathrm{C}$ for $20 \mathrm{~s}$, and $72{ }^{\circ} \mathrm{C}$ for $2 \mathrm{~min}$, with a 1-s autosegment extension for each cycle (Haley et al., 1994). A final extension cycle of $72{ }^{\circ} \mathrm{C}$ for 5 min was conducted before cooling the samples to $4{ }^{\circ} \mathrm{C}$. Amplified products were separated on $1 \%$ agarose gels containing ethidium bromide $\left(0.5 \mathrm{~g} \cdot \mathrm{mL}^{-1}\right)$ for $5 \mathrm{~h}$ at $3 \mathrm{~V} \cdot \mathrm{cm}^{-1}$ constant voltage.

Linkage analyses. RAPDs observed between contrasting DNA bulks were assayed across individual lines that comprised the bulks. RAPDs that cosegregated among lines within bulks then were screened across five $\mathrm{F}_{2}$ populations that segregated for the bgm-l gene. One dry bean population consisted of $91 \mathrm{~F}_{2}$ progeny derived from a XAN 176//T446/A429 hybridization. The T446/ A429 parent was an $\mathrm{F}_{5}$ line with nonmosaic resistance obtained from the previously mentioned RIL population. A population of 48 progeny was combined across the other four $\mathrm{F}_{2}$ populations involving 'Quest', 'Mirada', 'Seville', and 'Duchess' snap beans crossed with $\mathrm{A} 429$, because the heterogeneity $\chi^{2}$ for 1:3 segregation for sease reaction amongst them was nonsignificant. Phenotypic disease reactions of $F_{2}$ populations were determined by greenhouse inoculations using viruliferous whiteflies (Beaver et al., 1994). Only one RAPD (codominant) marker was useful following $\mathrm{F}_{2}$ cosegregation analysis.

Chi-square tests for expected 1 (bgm-1bgm-1) partial nonmosaic resistance : 3 (Bgm- $1 \mathrm{Bgm}-1$; Bgm-1bgm-1) susceptible phenotypic segregation at the resistance gene locus and 1:2:1 genotypic segregation at the codominant RAPD marker locus were performed for both $\mathrm{F}_{2}$ populations. Maximum-likelihood formulae were used to estimate recombination frequencies between $b g m$ $l$ and the codominant RAPD marker in both $\mathrm{F}_{2}$ populations (Suiter et al., 1983).

The codominant RAPD marker found linked to the BGMV resistance locus was assayed across susceptible lines and cultivars to determine the range of germplasm in which the marker would be useful for indirect selection (Miklas et al., 1993, 
1996a; Young and Kelly, 1996). To ascertain maintenance of the original linkage orientation of the codominant RAPD marker to the alleles at the bgm- 1 locus after numerous meioses, advanced lines and cultivars known to possess the $b g m-1$ nonmosaic resistance from 'Garrapato' were likewise assayed for the resistance-linked codominant RAPD.

\section{Results and Discussion}

Only two RAPDs were tightly linked to the recessive $b g m-1$ gene from 'Garrapato' that conditions nonmosaic partial resistance to BGMV (Table 1). These RAPDs were amplified by the same primer R2 (5'-CACAGCTGCC-3') and were codominant, with the 530 and 570 base pairs (bp) fragment length alleles of the marker in repulsion- and coupling-phase linkage (Miklas et al., 1996a) with the recessive resistance allele $b g m-1$, respectively (Fig. 1). The ability of the DNA bulks to detect a codominant RAPD marker is due to the allelic homozygosity at the bgm- 1 locus for each RIL used in the DNA bulk analysis and the uniformity and reliability of field and greenhouse screening tests used to detect the nonmosaic partial BGMV resistance conditioned by the $b g m-1$ gene.

There were no recombinations between the codominant RAPD marker and $b g m-1$ loci detected in the dry bean $\mathrm{F}_{2}$ population, and only two recombinants were detected in the combined snap bean $\mathrm{F}_{2}$ population $(4.2 \mathrm{cM})$ (Table 1$)$. In several other snap bean $\mathrm{F}_{2}$ populations (data not reported), recombination averaged $11.0 \mathrm{cM}$ between $\mathrm{R} 2_{570 / 530}$ and the $b g m-1$ gene. The difference in recombination frequency between the two population types might be attributed to higher recombination suppression occurring in one population vs. the other, which generally has been observed when linked loci have been transferred between, rather than within, common bean gene pools (Young and Kelly, 1996). See Singh et al. (1991) for a review of race and gene pool delineation of common bean germplasm. Observing a loose linkage in exotic $\mathrm{F}_{2}$ snap bean populations suggested that linked loci might be of Andean origin or perhaps traced back to an outcross Phaseolus species, such as $P$. coccineus, with known accessions having apparent immunity to BGMV (Beebe and Pastor-Corrales, 1991). Based on seed and agronomic characteristics, 'Garrapato' belonged to the Durango race within the middle American gene pool, which apparently represented the origin of $b g m-1$ and the codominant RAPD marker R2 $2_{570 / 530}$.

Survey of susceptible common bean lines and cultivars for presence of the respective 570-bp and 530-bp fragment alleles of the codominant RAPD (Table 2 ) revealed that the marker was gene

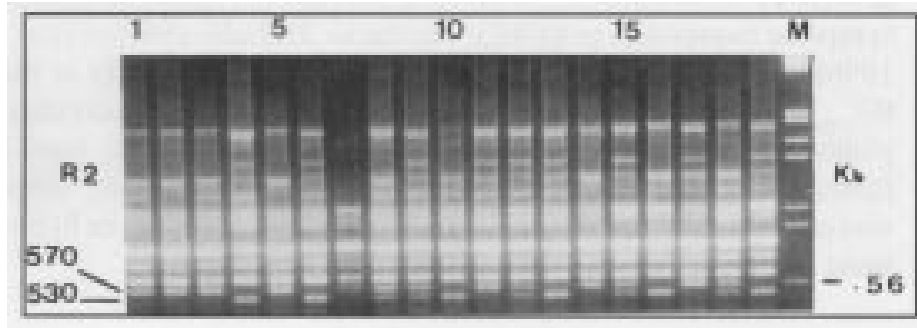

Fig. 1. Occurrence of the R2 $2_{570 / 530}$ codominant RAPD marker in snap bean. Snap parents (lanes 1 to 3 and 5), A429 parent (lane 4), and resistant control (lane 6). $\mathrm{F}_{2}$ segregants: lanes 7 to 19 . R2 $2_{570 / 530}$ phenotype: $-/+, 570$ base pair- (bp) fragment allele absent/530-bp fragment allele present, and the RAPD configuration indicating homozygous resistance ( $\mathrm{bgm}$ - $1 \mathrm{bgm}$ - 1 ) at the linked recessive $\mathrm{bgm}$ - 1 gene locus; +/+ both fragment alleles present indicating heterozygous susceptible (Bgm-1bgm-1); and +/-, 570-bp fragment allele present/530-bp fragment allele absent indicating homozygous susceptible $(B g m-1 B g m-1)$. M corresponds to the DNA molecular size marker HindIII/EcoRI digest of DNA.
Table 2. Survey of the R2 $2_{570 / 530}$ codominant RAPD marker linked to the bgm-1 resistance gene across susceptible germplasm, parents, and controls with 'Garrapato'-derived nonmosaic partial resistance to bean golden mosaic virus (BGMV).

\begin{tabular}{|c|c|}
\hline Germplasm $^{\mathrm{z}}$ & $\mathrm{R} 2_{570 / 530}$ \\
\hline \multicolumn{2}{|c|}{ Kidney and miscellaneous (A) } \\
\hline CELRK & $+/-^{y}$ \\
\hline Linden & $+/-$ \\
\hline Montcalm & $+/-$ \\
\hline Pompadour G & $+/-$ \\
\hline Cacahuate 72 & $+/-$ \\
\hline Royal Red & $+/-$ \\
\hline $3 \mathrm{M} 152$ & $+/-$ \\
\hline DOR 303 & $+/-$ \\
\hline \multicolumn{2}{|l|}{$\operatorname{Snap}(\mathrm{A}+\mathrm{MA})$} \\
\hline BelJersey-RR-14 & $+/-$ \\
\hline Early Gallatin & $+/-$ \\
\hline Sprite & $+/-$ \\
\hline \multicolumn{2}{|l|}{ Pinto (MA) } \\
\hline Arapaho & $+1-$ \\
\hline Bill Z & $+/-$ \\
\hline Othello & $+/-$ \\
\hline P 90521 & $+/-$ \\
\hline BelDakMi-RR-1, -2 & $+/-$ \\
\hline UI 114 & $+/-$ \\
\hline PX 057 & $+/-$ \\
\hline $2-2186$ & $+/-$ \\
\hline $3-4510$ & $+/-$ \\
\hline $3-4537$ & $+/-$ \\
\hline Garrapato & $-/+^{\mathrm{x}}$ \\
\hline JB 9226-5 & $-1+{ }^{x}$ \\
\hline TARS-VCI-4B & $+/-$ \\
\hline \multicolumn{2}{|l|}{ Black (MA) } \\
\hline B 190 & $+/-$ \\
\hline Turbo III & $-1+{ }^{\mathrm{x}}$ \\
\hline Negro 150 & $+/-$ \\
\hline Porrillo Sintetico & $+/-$ \\
\hline \multicolumn{2}{|l|}{$\operatorname{Red}(\mathrm{MA})$} \\
\hline PI 451895 & $+/-$ \\
\hline Dorado & $+/-$ \\
\hline Don Silvio & $-1+{ }^{x}$ \\
\hline Red Mexican 36 & $+/-$ \\
\hline \multicolumn{2}{|l|}{ White (MA) } \\
\hline Belmidak-RR-1 & $+/-$ \\
\hline Belmidak-RR-2 & $+/-$ \\
\hline Arroyo Loro & $+/-$ \\
\hline Seafarer & $+/-$ \\
\hline Schooner & $+/-$ \\
\hline Sanilac & $+/-$ \\
\hline C-20 & $+/-$ \\
\hline NX 040 & $+/-$ \\
\hline Mayflower & $+/-$ \\
\hline \multicolumn{2}{|l|}{ Parents } \\
\hline Quest (snap) & $+/-$ \\
\hline Mirada (snap) & $+/-$ \\
\hline Seville (snap) & $+/-$ \\
\hline Duchess (snap) & $+/-$ \\
\hline XAN 176 (black) & $+1-$ \\
\hline T446/A429 (pinto) & $-1++^{x}$ \\
\hline A429 (pinto) & $-1+{ }^{x}$ \\
\hline
\end{tabular}

${ }^{\mathrm{z}} \mathrm{A}$ and MA indicate germplasm of Andean and Middle American origin, respectively.

${ }^{\mathrm{y}} 2_{570} 530$ codominant RAPD marker genotype and corresponding genotype at the linked bgm-1 BGMV resistance gene locus: -/+ homozygous resistant (bgm-1bgm-1); +/+ heterozygous BGMV susceptible (Bgm-1bgm-1); and +/ - homozygous BGMV susceptible (Bgm-1Bgm-1).

'Lines and cultivars with BGMV resistance derived from 'Garrapato', but often obtained through hybridizations with the dry bean A429. 
pool nonspecific and, thus, useful for marker-assisted selection across a wide range of germplasm. A429 and 'Garrapato', the known source of $b g m$ - 1 , carried only the resistance- linked 530-bp fragment allele in repulsion-phase linkage with the recessive resistance allele $b g m-1$. 'Turbo III' and 'Don Silvio', derived from A429 (CIAT, 1995) and carrying the nonmosaic bgm- 1 resistance from 'Garrapato', also contained only the resistance-linked 530bp fragment allele. All susceptible lines and cultivars surveyed possessed only the susceptibility-linked 570-bp fragment allele in

Table 3. Advanced breeding lines with bgm-1-conditioned nonmosaic partial resistance to bean golden mosaic virus (BGMV) characterized for the linked $\mathrm{R} 2_{570 / 530}$ codominant RAPD marker. $^{\mathrm{Z}}$

\begin{tabular}{|c|c|c|c|}
\hline \multirow[b]{2}{*}{ Advanced line } & \multicolumn{2}{|c|}{ Reaction } & \multirow[b]{2}{*}{$\mathrm{R} 2_{570 / 530}$} \\
\hline & Greenhouse $^{\mathrm{y}}$ & Field $^{\mathrm{y}}$ & \\
\hline Arroyo Loro/DOR 482 & $\mathrm{R}^{\mathrm{x}}$ & & $-1+^{x}$ \\
\hline Arroyo Loro/DOR 482 & $\mathrm{R}$ & & $-1+$ \\
\hline Arroyo Loro/DOR 482 & $\mathrm{R}$ & & $-/+$ \\
\hline Arroyo Loro/DOR 482 & $\mathrm{R}$ & & $-1+$ \\
\hline Arroyo Loro/DOR 482 & $\mathrm{R}$ & & $-/+$ \\
\hline Arroyo Loro/DOR 482 & $\mathrm{R}$ & & $-/+$ \\
\hline Arroyo Loro/DOR 482 & $\mathrm{R}$ & & $-1+$ \\
\hline Arroyo Loro/DOR 482 & $\mathrm{~S}$ & & $+/+$ \\
\hline Red Mottled-1 & $\mathrm{S}$ & & $+/+$ \\
\hline Red mottled-2 & $\mathrm{S}$ & & $-1++^{\mathrm{w}}$ \\
\hline Red mottled-3 & $\mathrm{R}$ & & $-/+$ \\
\hline Red mottled-4 & $\mathrm{R}$ & & $-1+$ \\
\hline JB 9438-126 & $\mathrm{S}$ & & $+/-$ \\
\hline JB 9438-238 & $\mathrm{R}$ & & $-/+$ \\
\hline A429 & $\mathrm{R}$ & & $-1+$ \\
\hline DOR 483/BelNeb-RR-1 & & $\mathrm{R}^{\mathrm{v}}$ & $-1+^{\mathrm{v}}$ \\
\hline MUS 83/DOR 483 & & $\mathrm{R}$ & $-1+$ \\
\hline DOR 475/Triumph & & Seg. & $-1+^{u}$ \\
\hline DOR 475/Triumph & & Seg. & $-/+$ \\
\hline DOR 483/A429 & & $\mathrm{R}$ & $-/+$ \\
\hline DOR 483/A429 & & $\mathrm{R}$ & $-1+$ \\
\hline A429/Triumph & & $\mathrm{R}$ & $-/+$ \\
\hline DOR 483/BelNeb-RR-1 & & $\mathrm{R}$ & $-/+$ \\
\hline A429/Triumph & & $\mathrm{R}$ & $-1+$ \\
\hline DOR 482/9231-94 & & $\mathrm{R}$ & $+/{ }^{\mathrm{w}}$ \\
\hline DOR 303/T968 & & $\mathrm{R}$ & $+/-$ \\
\hline DOR 483/A429 & & $\mathrm{R}$ & $-/+$ \\
\hline DOR 483/A429 & & $\mathrm{R}$ & $-/+$ \\
\hline I 9449-33 & & $\mathrm{R}$ & $-/+$ \\
\hline DOR 483 & & Seg. & $+/+$ \\
\hline
\end{tabular}

${ }_{\mathrm{Z}} \mathrm{R} 2_{570 / 530}$ phenotype: -/+, 570-base pair (bp) fragment allele absent/530bp fragment allele present, and the RAPD configuration indicating homozygous resistance (bgm-1bgm-1) at the linked recessive gene locus; + + + both fragment alleles present indicating heterozygous susceptible (Bgm1 bgm-1); and +/-, 570-bp fragment allele present/530-bp fragment allele absent indicating homozygous susceptible (Bgm-1Bgm-1).

${ }^{y_{G}}$ Greenhouse inoculations using whiteflies (Beaver et al., 1994) viruliferous for the BGMV strain endemic to Puerto Rico and field reactions obtained by natural infection.

${ }^{\mathrm{x}}$ For each line, phenotypic greenhouse reaction to BGMV was averaged across three plants and the RAPD genotype was derived from pooled DNA.

wLines with recombination between linked loci.

${ }^{\mathrm{v}}$ For each line, phenotypic field reaction to BGMV was obtained on a plot basis, and the RAPD genotype was obtained from pooled DNA of three random plants grown in the greenhouse.

"Lines segregating could be either $+/+$ or $-/+$ depending on composition of the pooled DNA. coupling-phase linkage with $b g m-1$, indicating they were $B g m$ lBgm-1 genotypes.

The original linkage orientation between the 570- and 530-bp fragment alleles of the codominant RAPD and linked bgm- 1 gene persisted through the numerous meioses involved in development of advanced lines with nonmosaic partial resistance from 'Garrapato' (Table 3). Recombination between the linked loci were detected in only two advanced lines, Red mottled-2 and DOR 482/9231-94. The line DOR 303/T968 appeared to be recombinant for the linked loci because it had a different source of nonmosaic partial resistance derived from DOR 303 instead of 'Garrapato'.

Since there were higher recombination frequencies for snap bean between the marker and gene loci, we recommend that separate and distinct $\mathrm{F}_{1}$-derived populations or lines be maintained throughout any $\mathrm{R}_{2570 / 530}$-assisted snap bean backcrossing program. To monitor recombination, we recommend every third or fourth generation to screen the disease reaction of selfed progeny from parents heterozygous or homozygous for the 530-bp fragment allele. Also noteworthy, bgm-1 nonmosaic partial resistance by itself may not provide economic control of BGMV during moderate to severe epidemics. The most effective genetic control to BGMV is obtained through combined resistance. From field observations made in Puerto Rico, A429, which likely combines reduced mosaic and high yield from 'Porrillo Sintético' with bgm1 nonmosaic partial resistance from 'Garrapato', is more resistant than 'Garrapato' alone; moreover, 'Don Silvio', which likely combines the former two forms of resistance with an additional source, is slightly more resistant than A429.

The $\mathrm{R} 2_{570 / 530}$ codominant RAPD marker will be extremely useful for rapidly breeding BGMV resistance into all snap bean and susceptible dry bean market classes. First, the application of the marker is not limited by gene pool specificity (Table 1); therefore, it can be used for indirect selection of the bgm-1 gene across all common bean germplasm. Second, the marker is highly repeatable and easy to score, and has been amplified across several different laboratories using similar but distinct DNA extraction and PCR protocols. However, when using lower quality DNA obtained from mini-prep extraction protocols, a Stoffel fragment or similarly engineered DNA polymerase may be critical to the reaction. Third, by selecting $\mathrm{BC}_{n} \mathrm{~F}_{1}$ plants heterozygous for the marker as parents for subsequent backcrosses, it becomes unnecessary to develop and identify $\mathrm{BC}_{\mathrm{n}} \mathrm{F}_{2}$ parents with nonmosaic partial resistance every second to third backcross. Last, linkage of a codominant RAPD marker to a recessive resistance gene can be manipulated to facilitate gene pyramiding (M. Bassett, personal communication). For example, advanced near-inbred lines can be developed with resistance in the form of reduced or delayed mosaic symptom expression to BGMV similar to 'Dorado' (Miklas et al., 1996b), while simultaneously maintaining heterozygosity at the $\mathrm{R} 2_{570 / 530}$ locus. On selfing these lines and then selecting individual plants homozygous for the 530-bp fragment allele, the bgm-1 partial resistance can be effectively pyramided with any other source of BGMV resistance, be it independent, epistatic, or hypostatic to the phenotypic expression of the $b g m-1$ gene.

\section{Literature Cited}

Afanador, L.K., S.D. Haley, and J.D. Kelly. 1993. Adoption of a 'miniprep' DNA extraction method for RAPD marker analysis in common bean (Phaseolus vulgaris L.). Annu. Rpt. Bean Improv. Coop. 36:10-11.

Beaver, J.S., C.A. Mora, and D. de la Rosa. 1994. Screening for bean golden mosaic virus resistance in the greenhouse. Annu. Rpt. Bean Improv. Coop. 37:35.

Beebe, S. 1994. Breeding for resistance to bean golden mosaic virus: 
History and perspectives, p. 148-150. In: F. Morales (ed.) Bean golden mosaic: Research advances. Proc. Workshop PROFRIJOL and CIAT, Guatemala City, 9-13 Nov. 1992. CIAT, Cali, Colombia.

Beebe, S. and M. Pastor-Corrales. 1991. Breeding for disease resistance, p. 605-608. In: A. van Schoonhoven and O. Voysest (eds.) Common beans: Research for crop improvement. C.A.B. Intl., London.

Blair, M.W. and J.S. Beaver. 1993. Inheritance of bean golden mosaic resistance from bean genotype A429. Annu. Rpt. Bean Improv. Coop. 36:143.

Blair, M.W., M.J. Bassett, A.M. Abouzid, E. Hiebert, J.E. Polston, R.T. McMillian, Jr., W. Graves, and M. Lamberts. 1995. Occurrence of bean golden mosaic virus in Florida. Plant Dis. 79:529-533.

Centro Internacional de Agricultura Tropical. 1995. Catalog of advanced bean lines from CIAT. 2nd ed. M.A. Rodríguez, H.F. Ramírez, M.C. Valencia, O. Voysest, and J.W. White (eds.). Centro Internacional de Agricultura Tropical, Cali, Colombia.

Gálvez, G.E. and F.J. Morales. 1989. Whitefly-transmitted viruses, p. 380-387. In: H.F. Schwartz and M. Pastor-Corrales (eds.). Bean production problems in the tropics, 2nd ed. Centro Internacional de Agricultura Tropical, Cali, Colombia.

Haley, S.D., L.K. Afanador, P.N. Miklas, J.R. Stavely, and J.D. Kelly. 1994. Heterogeneous inbred populations are useful as sources of nearisogenic lines for RAPD marker localization. Theor. Appl. Genet. 88:337-342.

Johnson, E., P.N. Miklas, J.R. Stavely, and J.C. Martínez-Cruzado. 1995. Coupling- and repulsion-phase RAPDs for marker-assisted selection of the PI 181996 rust resistance in common bean. Theor. Appl. Genet. 90:659-664.

Kelly, J.D. 1995. Use of random amplified polymorphic DNA markers in breeding for major gene resistance to plant pathogens. HortScience 33:461-465.

Maxwell, D.P., R.L. Gilbertson, S.F. Hanson, J.C. de Faria, P. Ahlquist, W. McLaughin, and F.J. Morales. 1994. Genetic diversity of beaninfecting whitefly-transmitted gemini viruses, p. 113-114. In: F. Morales (ed.) Bean golden mosaic: Research advances. Proc. Workshop
PROFRIJOL and Centro Internacional de Agricultura Tropical, Guatemala City, $9-13$ Nov. 1992. Centro Internacional de Agricultura Tropical, Cali, Colombia.

Michelmore, J.L., I. Paran, and R.V. Kesseli. 1991. Identification of markers linked to disease resistance genes by bulked segregant analysis: A rapid method to detect markers in specific genomic regions by using segregating populations. Proc. Natl. Acad. Sci. USA 88:9828-9832.

Miklas, P.N., J.R. Stavely, and J.D. Kelly. 1993. Identification and potential use of a molecular marker for rust resistance in common bean. Theor. Appl. Genet. 85:745-749.

Miklas, P.N., L. Afanador, and J.D. Kelly. 1996a. Recombination-facilitated RAPD marker-assisted selection for disease resistance in common bean. Crop Sci. 36:86-90.

Miklas, P.N., E. Johnson, V. Stone, J.S. Beaver, C. Montoya, and M. Zapata. 1996b. Selective mapping of QTL conditioning disease resistance in common bean. Crop Sci. 36:1344-1351

Morales, F.J. and A.I. Niessen. 1988. Comparative responses of selected Phaseolus vulgaris germplasm inoculated artificially and naturally with bean golden mosaic virus. Plant Dis. 72:1020-1023.

Morales, F.J. and S.P. Singh. 1991. Genetics of the resistance to bean golden mosaic virus in Phaseolus vulgaris L. Euphytica 52:113-117.

Singh, S.P., J.A. Gutierrez, A. Molina, C. Urrea, and P. Gepts. 1991. Genetic diversity in cultivated common bean: II. Marker-based analysis of morphological and agronomic traits. Crop Sci. 31:23-29.

Suiter, K.A., J.F. Wendel, and J.S. Case. 1983. LINKAGE-1: A PASCAL computer program for the detection and analysis of genetic linkage. J. Hered. 74:203-204.

Welsh, J. and M. McClelland. 1990. Fingerprinting genomes using PCR with arbitrary primers. Nucl. Acids Res. 24:7213-7218.

Williams, J.G.K., A.R. Kubelik, K.J. Livak, J.A. Rafalksi, and S.V. Tingey. 1990. DNA polymorphisms amplified by arbitrary primers are useful as genetic markers. Nucl. Acids Res. 18:6531-6535.

Young, R.A. and J.D. Kelly. 1996. RAPD markers flanking the Are gene for anthracnose resistance in common bean. J. Amer. Soc. Hort. Sci. 121:37-41. 